\title{
KOVÁCS HENRIK
}

\section{A LIPPOZOO OKTATÁSMÓDSZERTANI ESZKÖZ ISMERTETÉSE}

\author{
Magyar Táncmüvészeti Egyetem- Néptánc Tanszék
}

\begin{abstract}
Absztrakt
A LippoZoo elsősorban kisgyermekek mozgásoktatására készült, színes állatfigurákat ábrázoló korongokból álló oktatásmódszertani eszköz. Célja, hogy játékos formában alapozza meg a tanulók néptáncos tudását, katalizálja mozgástanulási folyamataikat, fejlessze mozgáskoordinációjukat. Mindezek mellett távlati célja, hogy a gyerekeket játékos módon vezesse be a táncot kódoló szimbólumok rendszerébe. Néptánc- és testnevelésórák tananyagaként is használható.

Az ismertetés első felében rövid bevezető tekinti át a LippoZoo létrejöttét megalapozó elméleti hátteret és a néptáncoktatásban használatos hasonló rendszerű eszközöket. A második fejezet a LippoZoo eddig megjelent kiadásainak leírását tartalmazza. A harmadik egység a LippoZoo oktatási folyamatban levő helyét és a felhasználás módjait ismerteti.
\end{abstract}

\section{A LippoZoo előzményei}

A magyar néptánctanítási gyakorlatban széles körűen elterjedt a népi játékok és a népi játékokra épülő, azokat a célnak megfelelően módosító feladatok alkalmazása (Kiss, 2003, Sándor, 2005 és 2018, Lázár, 2007, Benedek és Sándor, 2006 és 2010; Czinóber, 2008, Wirkerné, 2008, Lévai, 2010, 2015, Balatoni és Kovács, 2014, Balatoni, 2016). A módszertani eszköztár újabb keletű csoportját képzik azok a segédeszközök, melyek a mindennapi élet számtalan területén megjelenő szimbolikus analógiákra' építve katalizálják a néptánctanítást. A zeneoktatásban hasonló kiindulási alapokkal a Heinrich Ullrich által kifejlesztett Ulwilla módszert használják (Ullrich és Vető, 2006), míg a Magyar Mozgáskotta Módszert testnevelési célzattal alkalmazzák a kisgyermekek mozgásfejlesztésében.

A néptáncalapú jelrendszerek közül elsőként Lévai Péter eszközkészlete jelent meg a Magyar Táncművészeti Főiskola tananyagában a 2010-es évek elején (a

1 A szimbólumok sűrített jelentését megtaláljuk többek között a közlekedési táblák, jelzések, piktogramok, kézjelek vagy akár az írás, a kotta vagy a tánclejegyzések területén is. Vagyis a szimbólumok segítségével végzett tanítás nem egy teljesen új, ismeretlen módszertani lehetőséget, hanem a tanulók számára már ismert, jól bevált információközlést jelent. 
rendszer publikálására 2018-ban került sor), melyben geometriai formák segítségével kódolták a magyar néptánc fő motívumtípusait. A Lévai-féle rendszer fő motívumtípusait alapul véve - azonban azokat kissé módosítva, a mozgás lényegi elemeit kiemelve -, a geometriai formákat az „Így tedd rá!" program jelképére cserélve Balatoni Katalin és Kovács Henrik 2014-ben publikálta a színes tulipánokból álló rendszert. Kovács Henrik egy évvel később, 2015-ben fejlesztette ki a LippoZoo eszköztárat². Elsődleges kiindulási alapjai egyrészt a magyar strukturalista néptáncelemzés eredményei (Martin és Pesovár, 1960, 1964, Szentpál, 1961, Fügedi és Kovács, 2014, Fügedi és Varga, 2014), másrészt a mozgás szerkezetét általánosabban kódoló „motif writing” (Hutchinson, 1983, Wile, 2013) tánclejegyzési rendszer. A LippoZoo létrejöttében másodsorban a Lévai és a Balatoni-Kovács rendszerek tapasztalatai játszottak szerepet.

\section{A LippoZoo korongjainak ismertetése}

Általánosságban elmondható, hogy a LippoZoo a fő motívumtípusok mellett az azokat felépítő mozdulat-összetételeket is tanítja. Lényege, hogy egyszerre ad információt az eltáncolandó mozdulattípusról és annak ritmusáról. Mindezt rendszerszerűen összefoglalva, játékos, motiváló formában tárja a táncosok elé. A lépések, az ugrások fő típusai, a gesztus és az érintés képi megjelenítésére állatfigurákat, míg a fél, negyed és a nyolcad ritmus kódolására színeket használ. Az így létrejövő színes állatfigurák rendkívüli módon motiválják a tanulókat, miközben észrevétlenül kialakítják a táncok újraalkotásában nélkülözhetetlen rendszerszemléletet.

A LippoZoo előbbiekben említett két fő kódolási módja közül elsőként tekintsük át a főbb mozdulattípusok szimbolikus megjelenítésére használt állatfigurákat, vagyis a LippoZoo formáját. Az adott mozdulattípus kódolására olyan állatot választottam, amely megjelenésével, jellemző mozgásával vagy életmódjával segít felidézni a mozdulat lényegét (1. ábra). A béka jelenti a páros lábról páros lábra ugrást. A gyalogkakukk mint az egyik leggyorsabban futó szárazföldi madár a futást, vagyis a váltó támasztékú ugrásokat kódolja. A medve "cammogása" a lépéseket, míg a gólya jellemző sziluettje az ismétlő támasztékú ugrásokat juttatja eszünkbe. A virágon ülő méhek a könnyedséget, súlynélküliséget, vagyis a támaszték helyett a földet érintő gesztust emelik ki. A nyolcszirmú virág a rajta ülő méhekkel egyetemben kiválóan segíti a 8+1 főirány megtanítását (Előre, jobb rézsút előre, jobb oldalra, jobb rézsút hátra, hátra, bal rézsút hátra, bal oldalra, bal rézsút előre, valamint az alapirány, azaz a helyben). A nyúl jellemző futásmódjából kiindulva - első ugrásakor a két hátsó lábáról az egyik mellsőre ugrik - a páros lábról egy lábra ugrást kódolja. A vízben élő polip kiválóan utal a kar, a láb vagy a törzs gesztusaira. Segítségével kódoljuk

2 A LippoZoo oktatási segédanyag 3 különböző csomagban (LippoZoo Kisdedóvó, LippoZoo Elemi Oskola és LippoZoo Elemi Oskola bővítője) 2016-ban jelent meg. Részletes leírás a csomagok tartalmáról a www.lippogo.hu/oktatasi-segedanyagok elérhetőségen. 
a magyar néptánc egyik legjellegzetesebb mozdulatait, a tapsot és a csapást. A polip nyolc karja - ahogy a nyolcszirmú virág - nagyon jól megjeleníti a 8+1 főirányt. Az egy támasztékról két lábra ugrást remekül példázza a kenguru. A farkáról elrugaszkodó két lábra érkező kenguru mozgását jól szemlélteti a BBC Natural History Unit által készített Life Story természetfilm-sorozatának egyik részlete. Kangaroo Boxing Fight. BBC Earth YouTube-csatorna: 01:09-01:15. https:// www.youtube.com/watch?v=WCcLMNcWZOc\&t $=85 \mathrm{~s}$

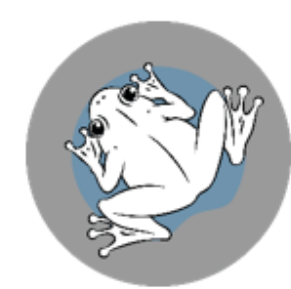

LippoZoo béka

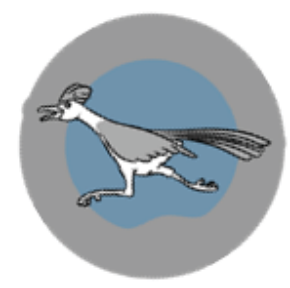

LippoZoo gyalogkakukk

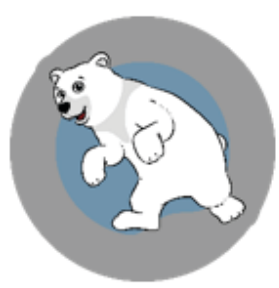

LippoZoo medve

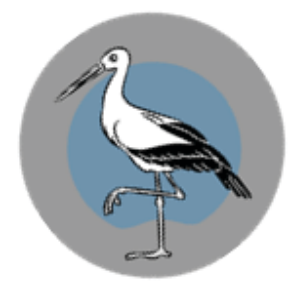

LippoZoo gólya

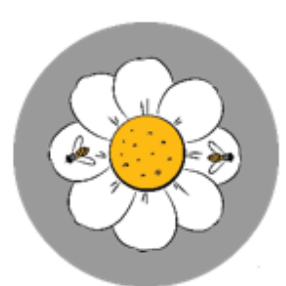

LippoZoo virág és méh

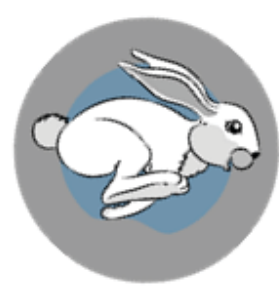

LippoZoo nyúl

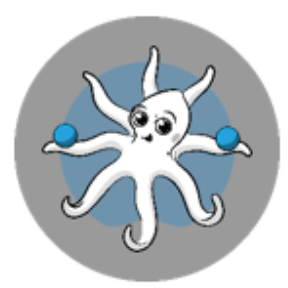

LippoZoo polip

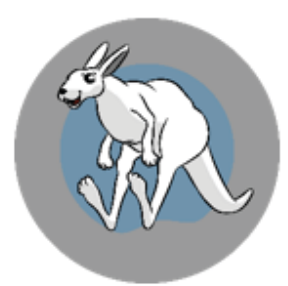

LippoZoo kenguru

1. ábra: A LippoZoo korongjai 
A LippoZoo színeket használ a mozdulatok ritmusának kódolására. A magyar néptáncra leginkább jellemző ritmuskombinációkat a következőek szerint jeleníti meg. A piros szín a fél ( (d), a sárga a negyed (J), a zöld a nyolcad-nyolcad-negyed ( \$\$d), a sötétzöld az előbbi augmentált változata, a negyed-negyed-fél (Jd), míg a kék a nyolcad-nyolcad (J) ritmusokat jelenti. A formát kiemelő, szín nélküli fehér korongok esetében a ritmust a táncosra bízzuk. Vagyis egyaránt lehet

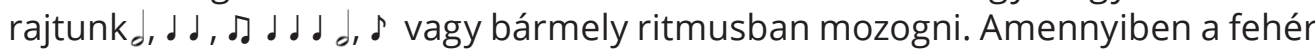
korongokat zenekíséret nélkül táncolják a tanulók, ők maguk választják meg a tempót is, és a ritmust is. Vagyis a mozdulatok gyorsasága igazodik a tanulók igényeihez. A rendszer a jelölt mozdulatok számát vagy a testoldaliságot sem köti meg. A folyamatosan bővülő Lippogó Folk YouTube-csatorna videói közül a „Tanuljunk LippoZoo-t! Fehér medve." és a „Tanuljunk LippoZoo-t! Fehér virág." felvételek adnak példát mozgóképen az előbbiekben leírtakra.

A teljes rendszer magában foglalja a nyolc különböző formájú (béka, gyalogkakukk, medve, gólya, méh a virágon, nyúl, polip, kenguru) korongot hatféle (piros, sárga, zöld, sötétzöld, kék, fehér) színváltozatban. Bizonyos esetekben az eltérő támasztékvariációk megjelenítésére szükséges volt bevezetni a "foltos" állatkorongokat. A 2. ábrán látható zöld béka szemlélteti a néptánc mozgalomban "höcögő"-ként ismert motívumot, mely a "mezőkomáromi csárdás" első ütemeiben is látható. A mezőkomáromi táncosok az utolsó „höcögő" motívumban (a linken elérhető film 5. másodpercében) azonban az utolsó ugrásra nem két lábra, hanem egy lábra ugrottak (Fügedi és Vavrinecz 2013 220, mozgóképen: http:// db.zti.hu/neptanc_tudastar/yt.asp?v=fBI87vYJZERc0). A LippoZoo ezt a motívumot a 3. ábrán látható „foltos” zöld nyúllal szemlélteti. A zöld szín jelenti, hogy J ১ ritmusban kell ugrani, a nyúl pedig azt mutatja meg, hogy két lábról egy lábra kell ugrani, vagyis ebben az esetben páros-páros-jobb a földön levő lábak sorrendje. A LippoZoo teljes rendszere összesen 79 különböző korongot ${ }^{3}$ tartalmaz, melyek igen tág lehetőséget biztosítanak a tanulók mozgáskoordinációjának fejlesztésére.

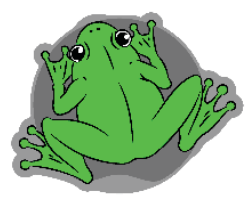

2. ábra: LippoZoo zöld béka

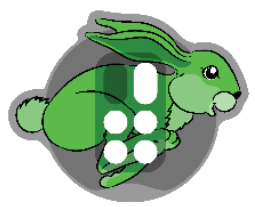

3. ábra: LippoZoo „foltos” zöld nyúl

3 A nyolc állatfigura hat színben összesen 48 korongot jelent, továbbá a rendszer 7 foltos korongot tartalmaz. Valamint a 7. ábrán látható polipon kívül van még másik négy polip is a rendszerben, melyek az igazgyöngyöt más-más karjukban tartják. Így további 24 koronggal bővül a készlet. Természetesen elképzelhetőek még további variációk is, de eddig már ez a készlet is jól lefedi, sőt meg is haladja a kisgyermekek korosztályának átadandó tananyagot. 
A LippoZoo eddig három különböző kiszerelésben érhető el. A Kisdedóvóban a piros béka, a sárga virág, a zöld medve és a sárga gólya található (4. ábra). Az általuk megjelenített motívumok gyakoriak a magyar néptáncban. Az Elemi Oskola csomag (5. ábra) tartalmazza az előbbi négy korongot, valamint a sárga békát, a piros virágot, a sárga medvét, a sárga és a zöld gyalogkakukkot és a sárga nyulat. Az Elemi Oskola csomag segítségével a magyar néptáncban leggyakrabban előforduló motívumokat tudjuk megjeleníteni. A fentiek alapján a XIX-XX. századi nevelési intézmények alapján elnevezett LippoZoo dobozok nevei nem a felhasználók életkorára, hanem a mozdulatok néptáncainkban való megjelenési gyakoriságára és nehézségeire utalnak. A tapasztaltok szerint az óvodáskorú gyerekek többsége is tudja és élvezi az Elemi Oskola korongjainak táncolását. Az Elemi Oskola Bővítője dobozban az összes fehér színű korong megtalálható. A dobozok minden korongból 6-6 db-ot tartalmaznak.
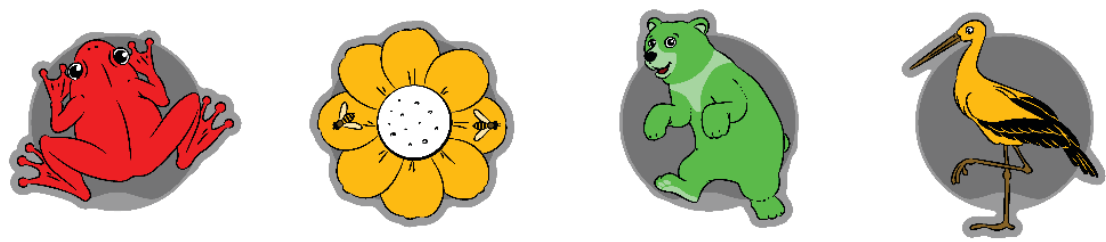

\section{4. ábra: LippoZoo Kisdedóvó}
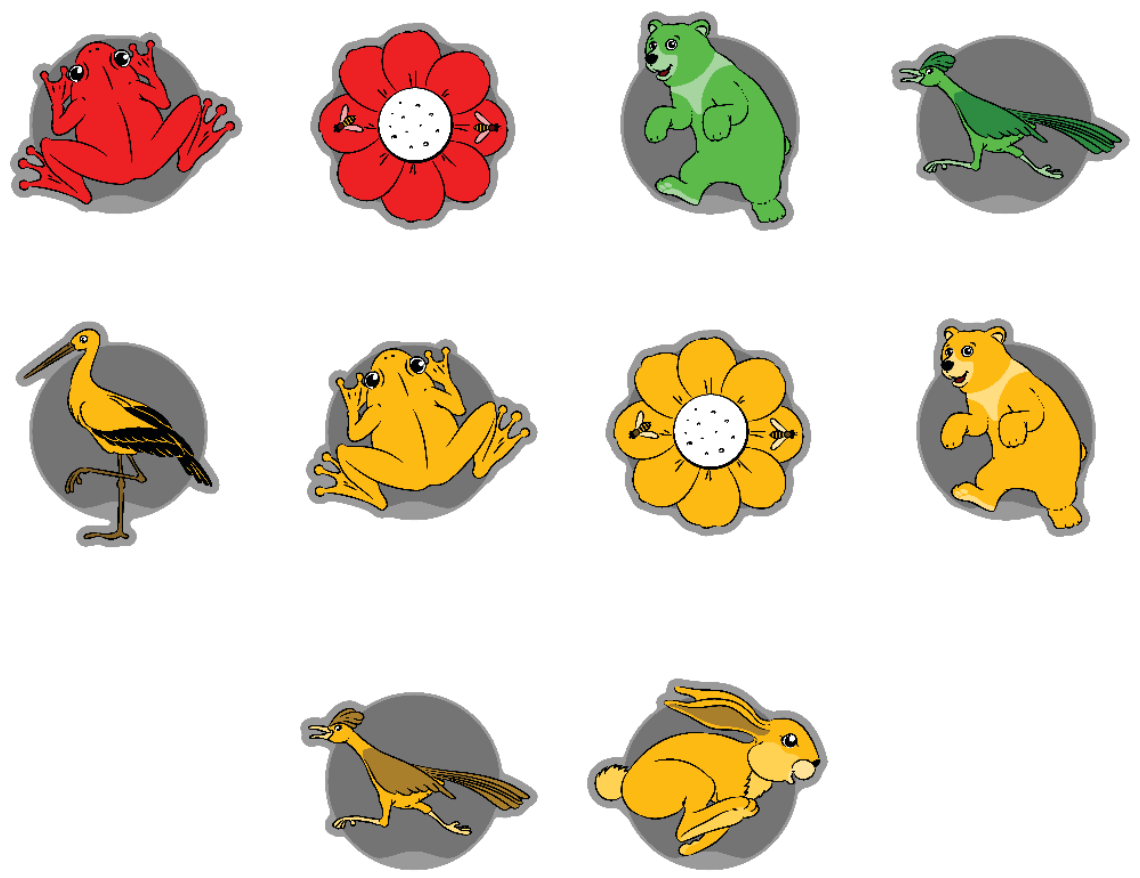

5. ábra: LippoZoo Elemi Oskola 
Az előbb ismertetetteknek megfelelően a sárga virág $d$, a piros virág $d$ ritmusú érintést jelent. A táncos dönti el, hogy hányszor és melyik lábával táncolja az érintést, melyek között táncolhat egy-egy lépést is. Az érintések lehetnek lábujjon, féltalpon, sarkon vagy akár talpon is. A piros béka d, míg a sárga d értékű páros lábú ugrásokat kódol. A „Tanuljunk LippoZoo-t! Piros béka variációk." és a „Tanuljunk LippoZoo-t! Sárga béka variációk." videókban látható, hogy nemcsak zárt lábbal, hanem változó számú ismétlésekkel terpeszben és oldalra is lehet táncolni a feladatot. A békák táncolása valójában a néptáncainkban rendkívül gyakori bokázókat jelenti. A sárga gólya a d-es, azonos lábon végzett ugrások szimbóluma. A tanuló táncolhatja jobb vagy akár bal lábbal is. Az ugrások ismétlésszáma legalább kettő legyen, a maximum nincs meghatározva. A sárga gólyával a "hegyezők”, „lengetők” és a csapások készíthetőek elő. A zöld medve a jól ismert J d ritmusú "cifra”, vagyis a háromlépés motívum. Míg a sárga medve a d-es ritmusú lépéseket kódolja, melyek alapvető részei többek között a csárdásoknak, a forgásoknak, az átvető motívumoknak, és találkozhatunk velük az ugrós táncokban is. A sárga nyúl esetében d d ritmusban ugrunk először páros lábra, majd egy lábra. Többszöri eltáncolásakor a lábsorrend lehet páros-jobb-páros-bal vagy páros-jobb-páros-jobb és természetesen páros-balpáros-bal is. A sárga nyúl a békákhoz hasonlóan a bokázó motívumot készíti elő. Nagy segítséget jelent a külső lábas bokázó forgások (pl.: szatmári, nyírségi, gömöri, szilágysági csárdások) megtanításában. A gyalogkakukkok a futást, vagyis az egyik lábról a másikra ugrást jelentik. Sárga színben d d, zöldben $\delta$ 」 ritmusban ugrunk, egyaránt kezdhetjük jobb vagy bal lábbal is. Mindkettő alapvető az ugrós táncok elsajátításához, de több más táncunk motívumaiban is rendszeresen előfordulnak.

\section{A LippoZoo felhasználásának módjai}

A következő fejezetben konkrét példák segítségével mutatom be a LippoZoo felhasználási módjait. Az alkalmazó természetesen a példák alapján saját maga is kitalálhat feladatokat. Például a korongok számának változtatásával, a korongok kiválasztásával, a szövegesen adott szabályok megadásával az adott pedagógiai célnak megfelelően állíthatják össze saját LippoZoo feladataikat a pedagógusok.

A korongokat alapvetően kétféle módon használhatjuk. Az egyik esetben a földre tesszük, a másikban magasan - a kezünkben vagy kivetítve - tartva mutatjuk a korongokat a táncosoknak. Ez a két fő felhasználási forma is további felhasználási altípusokra osztható.

\section{Földre helyezett korongok}

A földre helyezett korongoknak nagy szerepe van az adott motívum, mozgássor megtanulásakor. llyenkor tanítványaink egyszerre látják a LippoZoot és a hozzá kapcsolódó mozgásos feladatot. Hátránya, hogy a tekintetet lefelé irányítja, ami nem jellemző tánc közben. Ez kiküszöbölhető, ha egy tanórán, foglalkozáson 
arányaiban kevesebbet használjuk a földre helyezett korongokat, továbbá alkalmazzuk a magasan tartott LippoZookat.

2. Kötetlen forma

A kötetlen formában tetszőlegesen helyezzük a földre a korongokat. Ebben az esetben eleinte egyféle korongból tegyünk többet a földre! Későbbiekben bővíthetjük a feladatot más LippoZooval is. A kötetlen térforma előnye, hogy a növendékek maguk választhatják meg, hogy egy korongon mennyit táncolnak, több korong esetén, hogy melyiket választják. További előnye, hogy saját tempójukban haladhatnak. A kötetlen térformát további két módon tudjuk még osztani.

a. Kötetlen térforma nagy térközökkel (ritkás elrendezés)

Ebben az esetben a korongok között nagy távolságot hagyunk (6. és 7. ábrák). Érdemes olyan messze tenni, hogy ne lehessen az egyik korongról a másikra átugrani. A korongok között saját tempóban sétálva választhatják ki a következő LippoZoot. Ezzel a típusú kötetlen formával alakítjuk ki az eszközhöz és a tevékenységhez kapcsolódó pozitív hozzáállást, hiszen leginkább olyan feladatokat fognak választani a tanulók, amelyekben sikerélményük lesz.
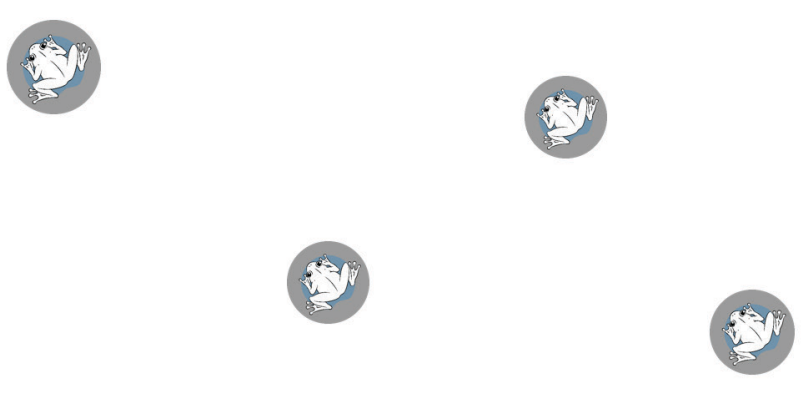

6. ábra: Kötetlen térforma nagy térközökkel egyféle LippoZooból
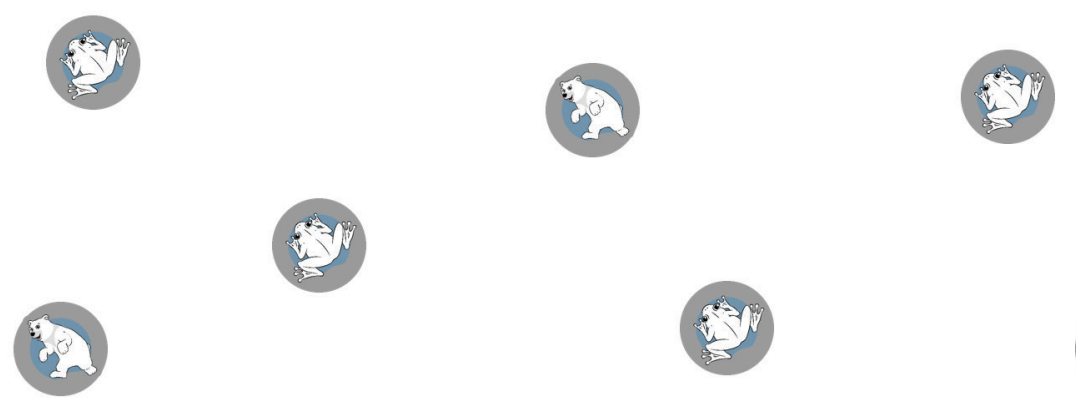

7. ábra: Kötetlen térforma nagy térközökkel kétféle LippoZooból 
b. Kötetlen térforma kis térközökkel (sűrű elrendezés)

Itt már olyan térközöket hagyunk a korongok között, hogy könnyedén át lehessen egyikről a másikra jutni. Többféle LippoZoo esetében (8. ábra) ez az elhelyezés lehetőséget ad arra, hogy a korongokat gyorsan váltogatva egyre nehezebb pályát alakítsanak ki maguknak a gyerekek. Ugyanakkor nem veszi el a lehetőséget a lassan, megfontolva haladástól sem. Így a sürűn elrendezett térforma alkalmas a differenciált oktatásra is. Egy időben, egy gyakorlaton belül a tehetségesebb és a lassabban haladó növendékek is kialakíthatják a maguk feladatsorát.

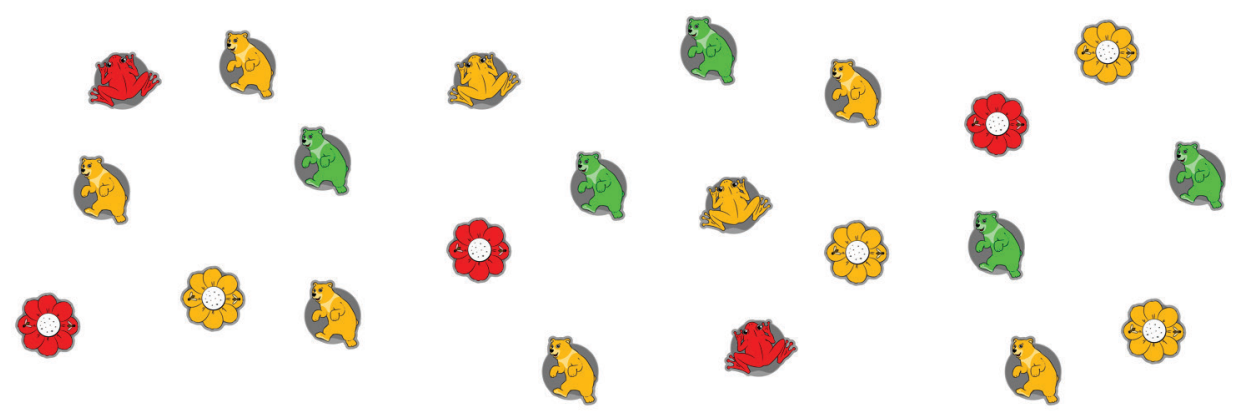

8. ábra: Sủrún kötetlen térforma többféle LippoZooból

A kötetlen formák többszöri gyakorlása után adjuk ki a következő feladatot: Képzelj el egy saját LippoZoo-pályát magadnak, ahol bármennyi és bármelyik korong lent lehet a földön a teremben bárhol, és járd végig! Ezzel a feladattal már saját rögtönzésre késztetjük a táncosainkat, a korongok elképzelésével továbbá egyfajta belső képet alkotnak a motívumokról, ami rendkívül hasznos lesz majd a későbbi tánctanulási szakaszban. Nem utolsó sorban a testtartásukat is helyes irányba tereli, hiszen ebben az esetben nem szükséges folyamatosan a földet nézni.

c. Kötött forma

A korongokat különböző alakzatokban is a földre helyezhetjük. Leggyakrabban sorban, körben vagy hullámvonalban rendezzük el, vagy eszközökkel kombinálva használjuk. Természetesen a pedagógus és a gyerekek fantáziája szerint sok más lehetőség is létezik. A kötött formához eleinte itt is érdemes csak egyféle korongot használni, amit a későbbiekben bővíthetünk más LippoZookal is. Egy alakzaton belül változtathatjuk az adott korongok számát is. Az egyféle korongból készített kötött formán az adott mozgást, motívumot sokszor kell eltáncolni. Így elsődleges szerepe a rögzítés. A többféle korongból álló kötött formák rendkívül alkalmasak motívumkapcsolatok és összetett motívumok tanítására.

d. Sorban elrendezett térforma

Az egyik legáttekinthetőbb, legkönnyebben megvalósítható térforma. A sorok kialakításakor figyeljünk a korongok és a sorok közötti távolságra. A gyakorló fázisban a korongok lehetnek „ugrástávolságon” kívül (amikor egyikről a másikra csak átsétálással lehet jutni), de gyakoribb az egymáshoz közeli elhelyezés. 
A sorok között akkora távolság legyen, hogy a mindkét soron egyszerre táncolók egymás mellett kényelmesen elférjenek! A 9. ábrán egyféle LippoZooból álló sorokat látni. A tanulók egyik sort táncolhatják a másik után. A gördülékeny újrakezdés miatt érdemes páros számú sorokat kialakítani. Másik lehetőség, hogy a tanulókat feloszthatjuk a soroknak megfelelő számú csoportra. Ebben az esetben minden csoport csak az egyik sort táncolja el többször, majd csoportcserékkel jutnak a másik LippoZoo-sorhoz (10. ábra).

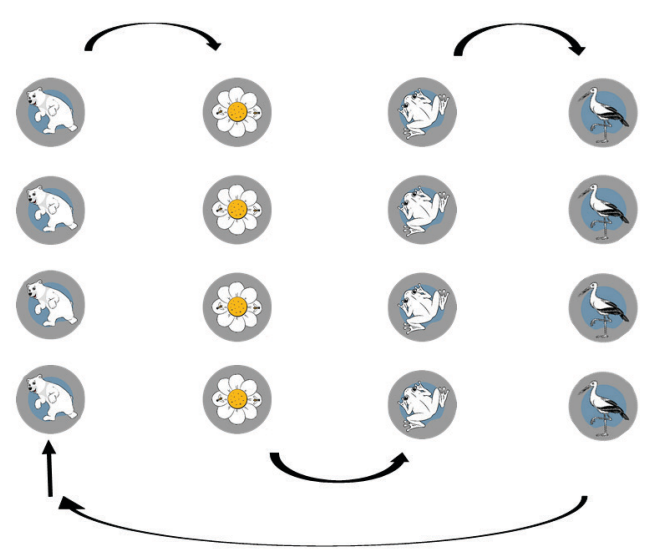

9. ábra: LippoZoo-sorok egyféle korongból egy nagy csoport részére 


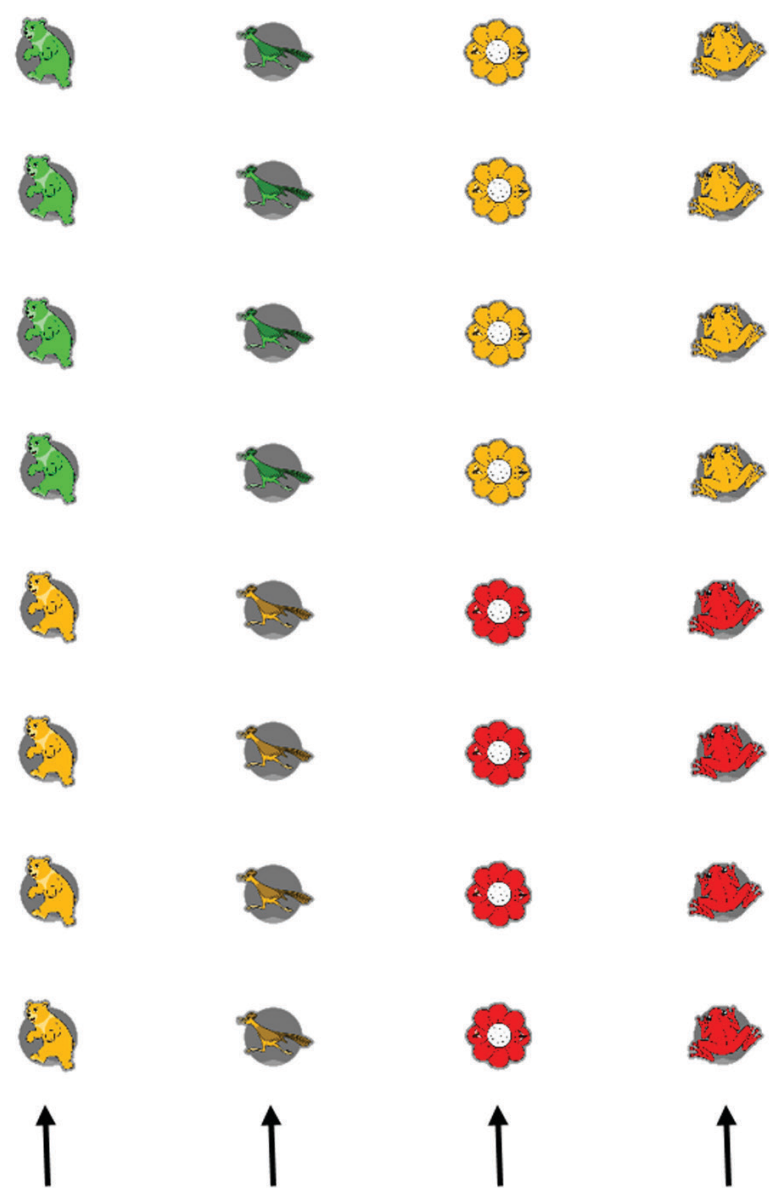

10. ábra: LippoZoo-sorok kétféle korongból négy kisebb csoport részére

A gyakorlatokat változatossá tehetjük a feladat ismétlésszámának módosításával. A „Tanuljunk LippoZoo-t! Fehér gyalogkakukk és gólya." felvételen az egyik irányba minden korongon két negyed hosszúságban, míg visszafelé már csak egy negyed hosszúságban kell ugrálni. A „Tanuljunk LippoZoo-t! Fehér béka és fehér gólya." című felvételen a motívumok ismétlésszáma korongonként egyik irányban kettő, míg a másik irányban már csak egy. A „Tanuljunk LippoZoo-t! Fehér medve és nyúl." felvételen a mozdulatok ismétlésszámát határoztuk meg: a medvéken kétszer táncoljuk el a d-es lépést, a nyulakon is kétszer táncoljuk el a feladatot, ami ebben az esetben így már d J J J ritmusú lesz. Visszafelé az ismétlésszámokat felére csökkentjük: medvén egy d-es lépés, nyúlon egyszer a d J ritmusú páros és egy lábas ugrások. A „Tanuljunk LippoZoo-t! Sárga és zöld gyalogkakukk.” felvételen a sárga gyalogkakukkokon a fenti elvet követi a táncos, míg a zöld gyalogkakukkokon mindig végigtáncolja a J J ritmust. Az ismétlésszámot azonban változtatja: egyik irányba négyszer, míg visszafelé már csak háromszor járja a háromugróst. 
A tánc és a zene izgalmas viszonyát hozza létre a színek és az ismétlésszámok összeállításával a „Tanuljunk LippoZoo-t! Piros és sárga béka." videón látható feladat. A „Tanuljunk LippoZoo-t! Színes békák és gyalogkakukkok." című felvételen két-két különböző béka és gyalogkakukk látható, mindegyikből csak 2-2 db. Így már egy nehezebb faladatot hoztunk létre csak ugrásokból, ami az állóképesség fejlesztésre is alkalmas. Nehezítésként megköthetjük, hogy egy soron belül nem előre, hanem oldalra kell haladni. Erre leginkább a békákat és a nyulakat ábrázoló korongok alkalmasak. Az így eltáncolt mozgássorok már az egyik legnehezebben megtanítható motívumok, a bokázók előképét fogják jelenteni.

A sorban elrendezett formának egy nehezebb változat látható a 11. és a 12. ábrákon. A két egymás melletti sort folyamatosan váltogatva a térbeliséget (a 11. ábrán az oldalra és előre haladást) vagy már összetettebb motívumokat (12. ábra) taníthatunk meg. A két sort és a soron belül a korongokat olyan távolságra tegyük, hogy a gyerekek könnyedén átugorhassanak egyikről a másikra.

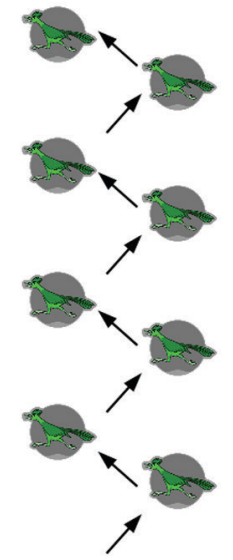

11. ábra: Sorban elrendezett eltolt forma egyféle LippoZooból

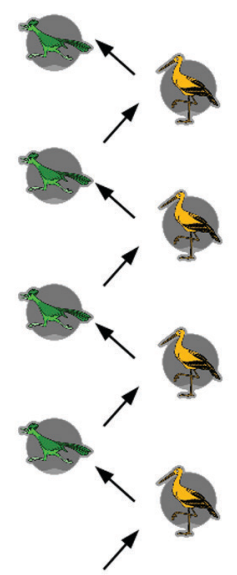

12. ábra: Sorban elrendezett eltolt térforma kétféle LippoZooból

e. Körben elrendezett térforma.

A tanulók létszámától és a terem méretétől függően egy nagyobb vagy több kisebb, esetleg koncentrikus köröket is kialakíthatunk. A korongok száma függ a célunktól. A 13. ábrán egy több LippoZooból álló gyakorlófeladat, míg a 14. ábrán egy jellegzetes ugrós motívumot előkészítő feladat látható (az eredeti motívum a sárga gyalogkakukkon kezdődik ${ }^{4}$. A kialakításkor ügyeljünk a megfelelő távolságokra. Az egy nagy körnek az előnye, hogy folyamatosan kell a feladatot végezni. Nem szükséges a feladatok közötti térváltás. Ugyanakkor ez nehézséget is jelent, hiszen a gyerekeknek folyamatosan koncentrálniuk kell, nincs lehetőség a feladatok váltása közötti lazításra.

4 A mezőföldi Alapon gyakori a motívum: férfi változata a 389.13-as számú ugrós felvételen, női változata a 389.14-es ugrós felvételen látható. 


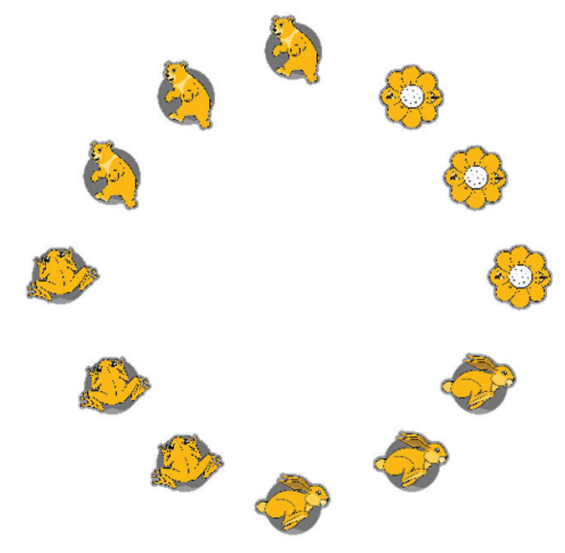

13. ábra: Körben elrendezett négyféle LippoZoo

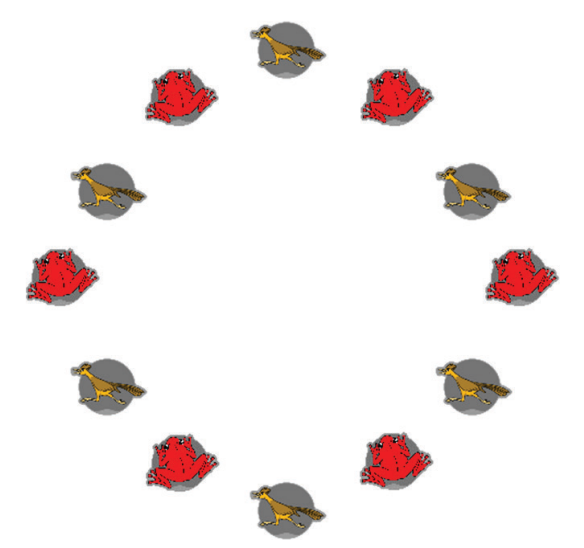

14. ábra: Körben elrendezett sárközi, mezőföldi ugrós motívumra rávezető feladat

f. Hullámvonalban elrendezett térforma A hullámvonal térforma rendkívül izgalmas feladatot ad tanulóinknak. Alakja motiválóan hat, ugyanakkor remekül fejleszti az egyensúlyt és a térérzékelést. A 15. ábra nemcsak a térforma, hanem a különböző LippoZook száma és a korongok mennyisége miatt is már egy nehezebb, több odafigyelést igénylő gyakorlatot mutat be.

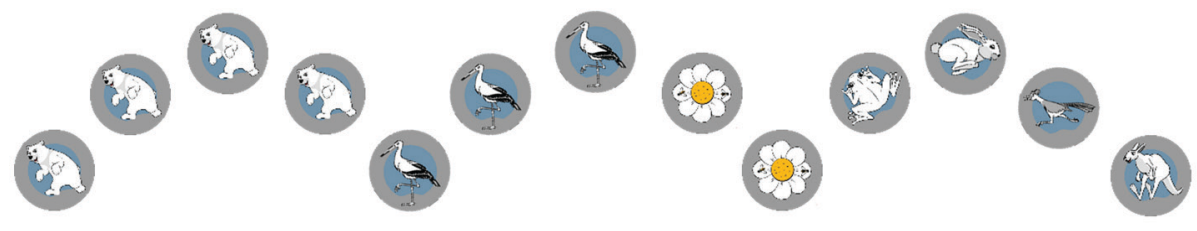

15. ábra: Hullámvonalban elrendezett nehezebb LippoZoo-pálya

g. Eszközökkel kombinált térforma

A LippoZoot eszközökkel együtt használva rendkívül változatos feladatokat állíthatunk össze. A botokkal, kötelekkel, hulahoppkarikákkal, babzsákokkal, üvegekkel stb. együtt használt korongok új kihívásokat jelentenek a gyerekeknek, és egyben rendkívül alaposan előkészítik az eszközös táncainkat.

A 23. ábrán a kanásztáncaink jellegzetes mozzanatát jelenítjük meg a keresztben lefektetett botok közötti zöld gyalogkakukkok segítségével (a halványabb nagybetűk a következő magyarázat értelmezése miatt kerültek az ábrára) pl.: "mezőkomáromi kanásztánc". A gyalogkakukkokat táncolhatjuk oldalirányba az „A" és $a$ " $D$ " vagy a " $B$ " és „ $D$ " térrészek között, elöre-hátra irányba az " $A$ " és a " $B$ " vagy $a z$ " $D$ " és a "C" térrészek között vagy rézsút irányokba az " $A$ " és a "C" vagy a " $D$ " és $a_{\text {„ }} \mathrm{B}^{\prime \prime}$ térrészek között. Nehezebb feladatként feladhatjuk a következő sorrendet:

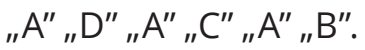




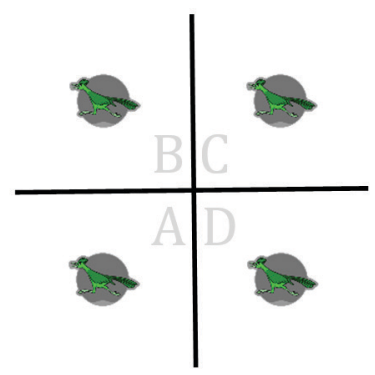

16. ábra: Kanásztánc zöld gyalogkakukkokból

Kötelek és békák segítségével könnyen rávezethetjük tanítványainkat a dunántúli friss csárdások bukós motívumára, pl.: „bagi friss csárdás”. A 17. ábra szerinti elrendezésben a piros békákra egyszerre ugrunk páros lábbal térdhajlításban 』ritmusban, míg a sárga békákra kétszer ugrunk páros lábbal J-es ritmusban. Így a táncpályán előre haladva folyamatosan táncoljuk a dd d ritmust.

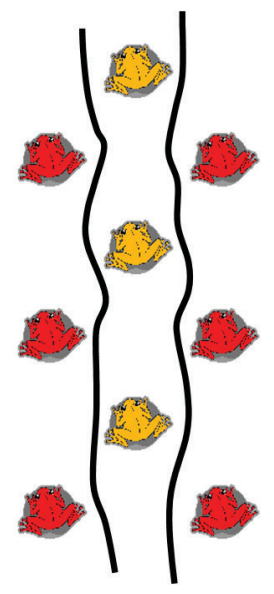

17. ábra: Bukós motívum békák és kötelek segítségével

\section{Magasan mutatott korongok}

A kezünkben magasan tartott vagy kivetített korongok a táncosok tekintetét felfelé irányítják. Ezáltal diákjaink testtartása a természeteshez közelít, és a tánchoz illőbbé válik. A földre helyezett korongoknál tapasztalható lefelé tekintést ezzel a móddal is kiküszöbölhetjük. A magasan mutatott LippoZook elsősorban a már elsajátított mozgássorok rögzítésére alkalmasak. Hiszen ebben az esetben már nem szükséges, hogy a korong és a mozgássor egy látótérben legyenek.

\section{A korongok felmutatása}

A tanórákon legkönnyebben megvalósítható, ha a tanár vagy egy diák mutatja a korongot a többieknek. A bemutatáshoz választhatunk egy korongot, de akár 
négyet is a kezünkben tarthatunk egyszerre. Utóbbinál egy-egy kezünkben tartunk két-két egymásra helyezett LippoZoot, amelyeket átfordítva tudunk váltogatni. Mindig tartsuk magasra azt a korongot, melynek mozgását viszont szeretnénk látni! Segíthetjük a táncolókat a korong színének megfelelő ritmusú apró mozdulatokkal. Komolyabb segítségként - és egyben a bemutatónak nehezebb feladatként a vezető táncolhatja az adott feladatot a többiekkel. A korongot bemutató választja meg, hogy egy feladatot mennyi ideig mutat a többieknek. Lehet többször (6-8 ismétléssel) kérni egy motívumot, de lehet akár motívumonként (egyszeri ismétléssel) is váltani a feladatokat. További nehezítést jelent, ha a vezető egyszerre két korongot felmutatva határozza meg a jobb és a bal oldalra váltva táncolandó motívumokat: bal karjában sárga gólyát, jobbjában piros békát tart, mindkettőt két negyed hosszan kéri. Ekkor a vele szemben állóknak jobbra jobb lábon kettőt kell ugrani d d ritmusban, majd balra kell ugorjanak páros lábra d ritmusban.

A korongok számának és a mutatásuk időtartamának változtatása mellett módosíthatjuk a résztvevők csoportosítását is:

1. Egy személy mutatja a csoport többi tagjának a feladatot. A tanár vagy a diák vezényli az egész csoportot. Egy adott személy ritkábban kerül sorra, így a táncosok sokat mozognak. Ezért jó megoldás, ha sok energiája van a csoportnak. Viszont nehezebb átlátni és javítani. Valamint biztos, hogy egy alkalommal nem lehet mindenki vezető. Az új vezetők általában mindig új korongokat választanak. A folyamatos tánc eléréséhez érdemes a következő vezetőt már akkor kiválasztani, amikor az előző vezényli a feladatot. Ezáltal folyamatosan mozgásban tarthatjuk a csoportot.

2. Egy személy mutatja egy kisebb csoportnak (3-6 fö). Ebben az esetben van arra idő, hogy egy foglalkozáson mindenki lehessen vezető. A kisebb csoportlétszám miatt az ellenőrzés és a javítás is sokkal könnyebb. A csoportok kialakulhatnak spontán módon is. Ugyanakkor a pedagógus a képességek szerint is elrendezheti a gyerekeket. Azonos képességűeket sorolhat egy csoportba, vagy egyenletesen elosztva a jobb képességúeket minden csoportba. Utóbbi esetben az ügyesebbek is példát mutatnak, kiegészítik a tanár szerepét.

3. A táncosok párban tevékenykednek. A „LippoZoo a Duna TV-ben” című videó 25. másodpercétől látható formában a táncosok egymással szemben állva vezetik egymás mozgását. Amennyiben csoportunkban minden pár magának választ korongot, és párcserét alkalmazunk, akkor egy foglalkozáson többféle LippoZoot is gyakorolnak a táncosok. A páros forma esetében van a legtöbb idő a pihenésre. Így hasznos feladat, ha már fáradtabbak a növendékeink.

A korongok kivetítése

A LippoZoot kivetíthetjük a táncosaiknak televízióra, számítógép képernyőjére vagy projektor segítségével vászonra, falra is. Váltogathatjuk képként a korongokat, de előre összeállíthatunk prezentációt is, ahol meghatározott sorrendben, akár előre beállított időközönként váltakoznak a LippoZook. A Lippogó Folk 
YouTube-csatornáján látható videók közül számtalan ötvözi a technika adta lehetőségeket. Egyszerre mutatva a korongot és a hozzá kapcsolódó mozgást vegyítik a földre helyezett és a magasan tartott korongok előnyeit: jól látható a LippoZoo, a hozzá tartozó motívum, és a tekintetet a magasban tartja.

Miután tanítványaink megismerkedtek a LippoZooval, ismernek több formát a felhasználási módok közül, bízzuk rájuk az adott feladatok kitalálását! Kreativitásuk rendkívüli, sok jó ötletet kaphatunk tőlük. Különböző szabályok kialakításával tehetjük érdekesebbé a feladatot:

- meghatározhatjuk a korongok számát (Egyféle korongból válassz bármenynyit, és készíts magadnak LippoZoo-pályát!),

- meghatározhatjuk az eltérő LippoZook számát (Válassz 4 különböző korongból bármennyit, és készíts magadnak LippoZoo-pályát!),

- meghatározhatjuk a korongok számát és a különböző LippoZook számát is (Válassz 6 különböző LippoZoot, mindegyikből kettőt, és készíts magadnak LippoZoo-pályát!),

- meghatározhatjuk a térformát (Készíts magadnak kör formájú LippoZoo-pályát!),

- meghatározhatjuk az eszközök használatát (Használd a LippoZoot hulahoppkarikákkal együtt!),

- meghatározhatunk csoportbontást (Alkossatok két csoportot! Mindkét csoport készítsen egy LippoZoo-pályát a másik csoport részére!).

A lehetőségek határtalanok. Táncpedagógus kollégák merítettek ihletet a LippoZooból, és használják különböző formákban. Álljon itt két példa: Podpácz Beáta a közismert Bingó játék négyzethálóját töltötte fel LippoZoo feladatokkal. Egész tanórákat játsszanak végig a Bingó játékszabályai szerint LippoZoot táncolva. A digitális oktatásban is megjelent a LippoZoo. Láda Júlia a wordwall.net honlapon készített szerencsekerék típusú feladatot LippoZooból.

Záró gondolatként essék szó a LippoZoo oktatási folyamatban betöltött szerepéről. Az eszköztár elsődleges célja a mozgástanulás katalizálása, a gyerekek motiválása és a rendszerszemlélet kialakítása. Ennek következtében a néptánc tanításnak egyik módszertani lehetőségét adja. Kiegészíti a pedagógus bemutatását, a közösen végzett gyakorlásokat, a konkrét tájegységek megtanulandó motívumainak elsajátítását. A LippoZoo elsősorban a néptánc megtanulásának előkészítésében játszik fő szerepet. A tanórák, foglakozások elején, a speciális tréningrészben kap helyet. Fő részként rövidebb órák és óvodáskorú gyerekek esetében jöhet szóba. A feladatok összeállításától és az óra céljától függően bizonyos esetekben kitöltheti a teljes foglalkozás fő részét, tárgyalását is. De általánosságban az órák negyedében-ötödében, vagyis 5-15 percen keresztül alkalmazzuk. A LippoZoo jellegéből adódóan nemcsak néptáncórák, hanem testnevelésórák tananyagát is képezheti. Az eddigi tapasztalatok és visszajelzések alapján zenetanárok és moderntánc-pedagógusok is előszeretettel használják. 


\section{IRODALOMJEGYZÉK}

„Kangaroo Boxing Fight." 2015. YouTube, közzétette BBC Earth, https://www. youtube.com/watch?v=WCcLMNcWZOc\&t=82s. 01:09-01:15. Letöltve: 2019. október 1.

„Tanuljunk LippoZoo-t! Fehér gyalogkakukk és gólya." 2020. YouTube, közzétette Lippogó Folk, https://www.youtube.com/watch?v=Q6Idz5SEPB U\&list=PL2Up9JDaztIY2q6iT7tCb30hGMeWD5m08\&index=3. Letöltve 2020. május 6.

„Tanuljunk LippoZoo-t! Fehér medve és nyúl." 2020. YouTube, közzétette Lippogó Folk, https://www.youtube.com/watch?v=7rifGpp-B3U\&list=PL2Up9JDaztlY2 q6iT7tCb30hGMeWD5m08\&index=7. Letöltve 2020. május 6.

„Tanuljunk LippoZoo-t! Fehér medve." 2020. YouTube, közzétette Lippogó Folk, https://www.youtube.com/watch?v=Rs0aznfmXU0\&list=PL2Up9] DaztlY2q6iT7tCb30hGMeWD5m08\&index=14. Letöltve 2020. május 6.

„Tanuljunk LippoZoo-t! Fehér virág.” 2020. YouTube, közzétette Lippogó Folk, https://www.youtube.com/watch?v=ib/WMYb0wyY\&list=PL2Up9JD aztlY2q6iT7tCb30hGMeWD5m08\&index=11. Letöltve 2020. május 6.

„Tanuljunk LippoZoo-t! Piros béka variációk." 2020. YouTube, közzétette Lippogó Folk, https://www.youtube.com/watch?v=RSYqYH5pWJU\&list= PL2Up9JDazt|Y2q6iT7tCb30hGMeWD5m08\&index=10. Letöltve 2020. május 6.

„Tanuljunk LippoZoo-t! Piros és sárga béka." 2020. YouTube, közzétette Lippogó Folk, https://www.youtube.com/watch?v=YsoxHdqQwNY\&list= PL2Up9JDaztlY2q6iT7tCb30hGMeWD5m08\&index=1. Letöltve 2020. május 6. „Tanuljunk LippoZoo-t! Sárga béka variációk." 2020. YouTube, közzétette Lippogó Folk, https://www.youtube.com/watch?v=c4WvzvNAQzY\&list= PL2Up9JDazt|Y2q6iT7tCb30hGMeWD5m08\&index=16. Letöltve 2020. május 6.

„Tanuljunk LippoZoo-t! Sárga és zöld gyalogkakukk." 2020. YouTube, közzétette Lippogó Folk, https://www.youtube.com/watch?v=tUhmsSIAVeQ\&list= PL2Up9JDaztlY2q6iT7tCb30hGMeWD5m08\&index=6. Letöltve 2020. május 6. „Tanuljunk LippoZoo-t! Színes békák és gyalogkakukkok." 2020. YouTube, közzétette Lippogó Folk, https://www.youtube.com/watch?v=fjWPo1kMB5A\&list= PL2Up9JDaztlY2q6iT7tCb30hGMeWD5m08\&index=12. Letöltve 2020. május 6.

Balatoni Katalin és Kovács Henrik (2014). Így tedd rá! 2. Ráckeve, Saramis Bt.

Balatoni Katalin (2016). Így tedd rá! Saramis Bt. X. kiadás.

Benedek Krisztina és Sándor Ildikó (2006). Útravaló. A néphagyomány közvetítésének módszerei az óvodában. Budapest, Hagyományok Háza, Népmúvészeti Módszertani Múhely.

Benedek Krisztina és Sándor Ildikó (2010). Útravaló 2. A néphagyomány közvetítésének módszerei az iskolában. Budapest, Hagyományok Háza, Népművészeti Módszertani Múhely. 
Czinóber Klára (2008). Népi játék, mozdulattípus, néptánc módszertan. Játék, mozdulat, tánc, szerkesztette Sándor Ildikó, Budapest, Hagyományok Háza, Népművészeti Módszertani Műhely, pp. 7-61.

Friss csárdás. 1953. Gyűjtötte Szőts István, MTA BTK Zenetudományi Intézet Néptánc Archívum, Ft.201.3. Filmfelvétel.

Fügedi János és Kovács Henrik, szerkesztők (2014). Mezőföldi ugrósok: Táncelemzések. Budapest, L'Harmattan Kiadó/MTA BTK Zenetudományi Intézet. Az európai régi táncréteg: Ugrós monográfiák.

Fügedi János és Varga Sándor (2014). Régi tánckultúra egy baranyai faluban. Budapest, L'Harmattan Kiadó/MTA BTK Zenetudományi Intézet. Az európai régi táncréteg: Ugrós monográfiák.

Hutchinson Ann (1983). Your Move: A New Approach to the Study of Movement and Dance. New York: Gordon and Breach.

Kanásztánc. 1942. Előadta Progl Ferenc, gyűjtötte Molnár István, MTA BTK Zenetudományi Intézet Néptánc Archívum, Ft.6.1a-c. Filmfelvétel.

Kiss Zsuzsanna (2003). „Népi gyermekjátékaink.” Ugrós táncaink, szerkesztette Zórándi Mária, Budapest, Planétás Kiadó, pp. 18-35.

Láda Júlia (2020). LippoZoo. Wordwall, közétette Eotvosjulia, https://wordwall. net/hu/resource/1511787/m\%c5\%b1v\%c3\%a9szet/lippozoo. Letöltve 2020. május 3.

Lázár Katalin (1997). Népi játékok. Jelenlévő múlt, Budapest, Planétás Kiadó.

Lévai Péter (2010). Szökkenjünk, ugráljunk. A sárközi ugrós táncok tanítási módszertana. Magyar Kultúra Kiadó.

Lévai Péter (2015). A mozdulattípusok tanítása egyszerü eszközökkel és a zenei lüktetés értelmezése a táncelőkészítésben Kétnyelvü tanjegyzet IV. rész. Vyučba rôznych typov pohybu jednoduchýmiprostriedkami a interpretaciá tempá a rytmu hudobného sprievodu pri tanečnej príprave Dvojjazična metodická zbierka IV. čast. Regionalne osvetove stredisko v Leviciach Magyar Kultúra Kiadó.

Lévai Péter (2018). A mozdulattípusok tanítása egyszerü eszközökkel és a zenei lüktetés értelmezése a táncelőkészítésben. Kétnyelvü tanjegyzet V. rész. Vyučba rôznych typov pohybu jednoduchýmiprostriedkami a interpretaciá tempá a rytmu hudobného sprievodu pri tanečnej príprave Dvojjazična metodická zbierka IV. čast. Regionalne osvetove stredisko v Leviciach.

Lippogó Folk. YouTube, https://www.youtube.com/channel/UCCOIGaDWjQQ uuD9NFiWfpRg, YouTube-csatorna. Letöltve 2020. május 6.

LippoZoo a Duna TV-ben." 2020. YouTube, közzétette Lippogó Folk, https://www. youtube.com/watch?v=4J7-WJ9aa5s\&t=27s. Letöltve 2020. május 6.

Magyar Gábor. Magyar Mozgáskotta Módszer. http://www.mozgaskotta.hu/index. html. Letöltve 2020. április 2.

Martin György és Pesovár Ernő (1960). „A magyar néptánc szerkezeti elemzése: Módszertani vázlat." Tánctudományi Tanulmányok 1959-1960, szerkesztette Dienes Gedeon és Morvay Péter, Budapest, Magyar Táncművészek Szövetsége Tudományos Bizottsága, pp. 211-248. 
Martin György és Pesovár Ernő (1964). A motívumtípus meghatározása a táncfolklórban. Tánctudományi Tanulmányok 1963-1964, szerkesztette Dienes Gedeon, Budapest, Magyar Táncművészek Szövetsége Tudományos Bizottsága, pp. 193-234.

Mezőkomáromi csárdás. 1942. Előadták Progl Ferenc és Progl Mária, gyűjtötte Molnár István, MTA BTK Zenetudományi Intézet Néptánc Archívum, Ft.6.7a-c. Filmfelvétel.

Oktatási segédanyagok. Lippogó. http://lippogo.hu/oktatasi-segedanyagok. Letöltve 2020. április 11.

Sándor Ildikó (2005). Tücsökringató: Ölbeli játékok. Budapest, Hagyományok Háza, Népmúvészeti Módszertani Mühely.

Sándor Ildikó (2018). Kerekecske, kutacska: Újabb ölbeli játékok. Budapest, Hagyományok Háza.

Szentpál Olga (1961). „A magyar néptánc formai elemzése.” Ethnographia, 72. évf., 1. szám, pp. 3-55.

Ugrós. 1958. Előadták Fekti József és Fekti Józsefné Egyed Julianna, gyűjtötték Pesovár Ferenc és Martin György, MTA BTK Zenetudományi Intézet Néptánc Archívum, Ft.389.14a-c. Filmfelvétel.

Ugrós. 1958. Előadták Fekti József és Fekti Józsefné Egyed Julianna, gyűjtötték Pesovár Ferenc és Martin György, MTA BTK Zenetudományi Intézet Néptánc Archívum, Ft.389.14a-c. Filmfelvétel.

Ugrós. 1958. Előadták Ulicza János és Ulicza Jánosné Bernáth Rozália, gyűjtötték Pesovár Ferenc és Martin György, MTA BTK Zenetudományi Intézet Néptánc Archívum, Ft.389.13a-c. Filmfelvétel.

Ullrich, Heinrich és Vető Anna (1996). ULWILA színeskotta. Down Alapítvány.

Wile Charlotte (2013). Moving about: Capturing Movement Highlights Using Motif Notation. Printed by author.

Wirkerné Vasvári Éva (2008). Az óvodás korú gyermekek mozgásfejlesztése magyar népi játékokkal. Játék, mozdulat, tánc, szerkesztette Sándor Ildikó, Hagyományok Háza, Népmúvészeti Módszertani Műhely, Budapest, pp. 61-144.

\section{Szerző:}

Kovács Henrik

kovacshenrik@gmail.com

Magyar Táncművészeti Egyetem- Néptánc Tanszék 